\title{
Seroprevalence of Hepatitis B Surface Antigen (HBsAg) among Patients Attending a Tertiary Care Hospital at Chamarajanagar, Karnataka, India
}

\author{
Trupti B. Naik, J.V. Sathish* and Mita D. Wadekar \\ Chamarajanagar Institute of Medical Sciences, Chamarajanagara, Karnataka, India \\ *Corresponding author
}

\begin{tabular}{l} 
Key w o r d s \\
Hepatitis B surface \\
antigen, \\
Immunochromato \\
graphic assays, \\
Seroprevalence \\
\hline Article Info \\
$\begin{array}{l}\text { Accepted: } \\
\text { 12 December } 2017 \\
\text { Available Online: } \\
\text { 10 January } 2018\end{array}$ \\
\hline
\end{tabular}

\section{A B S T R A C T}

Hepatitis B virus (HBV) infection continues to be a serious public health problem globally. The study on its prevalence helps in estimating the magnitude of the problem in a community and identifies potential high risk groups. A hospital based study on seroprevalence of Hepatitis B surface antigen (HBsAg) gives an indirect estimate of disease burden in the community besides being useful in proper allocation of available resources at the hospital. To estimate seroprevalence of Hepatitis B surface antigen among patients at the study setting. A hospital based cross sectional study was conducted at a tertiary care hospital in Chamarajanagar, Karnataka. Secondary data maintained in the microbiology laboratory registers of patients tested for HBsAg by one step rapid immunochromatographic method from January 2016 to August 2017were included for analysis. Statistical analysis was done using Microsoft office excel 2010. A total of 6905 patients tested over a period of one year and eight months from January 2016 to August 2017. Seroprevalence rate in the present study was $39(0.56 \%)$. Majority of them were males i.e. $22(56.41 \%)$ and were in the age group of $21-40$ years. i.e. $24(61.53 \%)$.The present study demonstrates predominance of $\mathrm{HBV}$ infection in economically productive groups, highlighting the need to formulate strategies for its control and prevention.

\section{Introduction}

Hepatitis B virus (HBV) infection is a global public health problem and causes a spectrum of diseases ranging from self-limiting hepatitis to acute fulminant and chronic hepatitis leading to complications like liver cirrhosis and hepatocellular carcinoma. HBV infection is the cause of 5 th most common cancer and 10th leading cause of death worldwide (Quadri et al., 2013; Sood et al., 2013). As per recent estimates, 10 million new cases occur and nearly 350-400 millions of people become chronic carriers annually all over the world (Bulle et al., 2016). It is the cause of $30 \%$ cases of cirrhosis and $60-80 \%$ of all primary cancers in the liver. At any point in time, nearly $30 \%$ of the world's population shows serological evidence of current or past infection with HBV (Naqshbandi et al., 2016).

Prevalence of $\mathrm{HBV}$ infection varies greatly in different parts of the world. The World Health Organization (WHO) has classified HBV prevalence into high $(>8 \%)$, intermediate (2$7 \%)$ and low endemic $(<2 \%)$ areas and India 
falls in the intermediate range with an estimated 1,00,000 deaths per year. The primary routes of transmission are parenteral transmission like transfusion of blood and its products, dialysis, pricks by contaminated needles, accidental inoculation of infected blood during surgical and dental procedures, immunization, tattooing, ear/nose pricking etc., perinatal transmission from infected mother to child and sexual transmission (Quadri et al., 2013).

Diagnosis of HBV infection using serological markers varies depending on whether the infection is acute or chronic. Hepatitis B surface antigen (HBsAg) appears 1-7 weeks before biochemical markers of liver disease or jaundice become evident and remains in almost half of them even after 3 weeks after the onset of disease.

After initial infection, a proportion of patients fail to clear infectious material from the blood stream and become chronic carriers (Patil et al., 2011) and in them, the HBsAg persists for longer periods, sometimes for life. Further, a large proportion of patients suffering from Hepatitis B may remain asymptomatic and can transmit the infection to healthy population (Quadri et al., 2013).

Detection of HBsAg is the most commonly used test for diagnosing acute HBV infections as well as for detecting carriers (Naqshbandi et al., 2016) Immunochromatoragphy assays (ICA) are economical and do not require special instrumentation for analysis and have been recommended for routine use in clinical microbiology laboratories for detection of HBsAg (Sato, 1996). The speed, sensitivity and simplicity of the ICA method makes it more attractive, particularly for large-scale surveillance studies (Torlesse, 1997; Kaur, 200) With this background, the present study was undertaken to estimate seroprevalence of with the following objective.
To estimate seroprevalence of Hepatitis B surface antigen among patients at the study setting.

\section{Materials and Methods}

A cross sectional study was conducted at Chamarajanagar Institute of Medical Sciences, Chamarajanagar by collecting secondary data from laboratory registers of patients tested for HBsAg from January 2016 to August 2017. Prior permission for the study was obtained from concerned authorities. Demographic characteristics like age, gender, clinical details and HBsAg test results of the patients were collected.

\section{Detection of HBsAg}

A venous blood sample of $5 \mathrm{ml}$ was collected from patients with standard precautions. The blood was allowed to clot for 45 minutes at room temperature and the serum was separated after centrifugation.

The serum was then subjected to one step rapid immunochromatographic assay (ICA) Alere Trueline TM (Alere Medical Pvt. Ltd) kitfor detection of HBsAg following manufacturer instructions.

\section{Statistical analysis}

Statistical analysis was done using Microsoft Office Excel 2010.

\section{Results and Discussion}

Table 1 demonstrates age and gender wise distribution of patients tested for HBsAg. Out of the total 6905 patients tested for $\mathrm{HBsAg}$, majority i.e. $4679(67.76 \%)$ were females and majority i.e. $4427(64.11 \%)$ were in the age group of 21-40 years as seen in the table. 
Figure 1 shows seroprevalence of $\mathrm{HBsAg}$ among patients and out of the total 6905 patients tested for HBsAg, $39(0.56 \%)$ were positive.

Table 2 shows gender wise distribution of seropositive patients. Out of 39 seropositive cases, majority i.e. $22(56.41 \%)$ were males. Also the rate of seropositivity was higher among males $(0.98 \%)$ compared to females $(0.36 \%)$

Table 3 shows age and sex wise distribution of seropositive patients. Out of 39 seropositive cases, majority i.e. $24(61.53 \%)$ were in the age group of $21-40$ years followed 11 $(28.2 \%)$ cases in the $41-60$ years age group. Further analysis of the data revealed that the rate of seropositivity was directly proportional to the age groups as seen in the table. The present hospital based study analysed data of
6,905 samples processed over a period of one year and eight months from January 2016August 2017 at a tertiary care hospital in Chamarajanagar, Karnataka. The proportion of samples tested positive for HBsAg was 0.56 $\%$. Various studies done over the past 10 years in different places of the country showed prevalence ranging from $0.87 \%$ to $5.1 \%$ as depicted in Table 4. A prevalence rate of $0.87 \%$ was reported by Sood et al., (2013) in Jaipur similar to the findings of the present study. In a recent systemic review and metaanalysis of the prevalence of hepatitis B in India, the state of Andhra Pradesh, showed a prevalence of $3.25 \%$ in nontribal areas and $5.00 \%$ in tribal areas (Batham et al., 2009; Sood, 2013). Chowdhury (2004) reported that $3-4 \%$ of the Indian population are HBV infected with the highest prevalence among the aborigines of Andaman as well as from Arunachal Pradesh.

Table.1 Age \& Sex wise distribution of patients tested for HBsAg

\begin{tabular}{|c|c|c|c|c|c|c|}
\hline $\begin{array}{c}\text { Age in } \\
\text { years }\end{array}$ & \multicolumn{2}{|c|}{ Male } & \multicolumn{2}{c|}{ Female } & \multicolumn{2}{c|}{ Total } \\
\hline & No. & $\%$ & No. & $\%$ & No. & $\%$ \\
\hline $1-20$ & 280 & 12.57 & 434 & 9.27 & 714 & 10.34 \\
\hline $21-40$ & 1064 & 47.70 & 3363 & 71.87 & 4427 & 64.11 \\
\hline $\mathbf{4 1 - 6 0}$ & 700 & 31.44 & 658 & 14.06 & 1358 & 19.66 \\
\hline $\mathbf{6 1 - 8 0}$ & 182 & 8.17 & 224 & 4.78 & 406 & 5.87 \\
\hline Total & 2226 & 100 & 4679 & 100 & 6905 & 100 \\
\hline
\end{tabular}

Table.2 Gender wise distribution of seropositive patients

\begin{tabular}{|c|c|c|c|}
\hline Gender & All cases & Seropositive cases & $\begin{array}{c}\text { Rate of } \\
\text { seropositivity } \\
(\%)\end{array}$ \\
\hline Male & 2226 & $22(56.41 \%)$ & 0.98 \\
\hline Female & 4679 & $17(43.59 \%)$ & 0.36 \\
\hline Total & 6905 & $39(100 \%)$ & 0.56 \\
\hline
\end{tabular}


Table.3 Age and sex wise distribution of HBsAg positive patients

\begin{tabular}{|c|c|c|c|c|c|c|c|}
\hline Age in years & \multicolumn{2}{|c|}{ Male } & \multicolumn{2}{|c|}{ Female } & \multicolumn{2}{c|}{ Total } & Rate of seropositivity \\
\hline & No. & $\%$ & No. & $\%$ & No. & $\%$ & $\%$ \\
\hline $\mathbf{1 - 2 0}$ & 0 & 0 & 0 & 0 & 0 & 0 & 0 \\
\hline $\mathbf{2 1 - 4 0}$ & 14 & 63.63 & 10 & 58.82 & 24 & 61.53 & 0.54 \\
\hline $\mathbf{4 1 - 6 0}$ & 6 & 27.27 & 5 & 29.41 & 11 & 28.2 & 0.81 \\
\hline 61-80 & 2 & 9.09 & 2 & 11.76 & 4 & 10.25 & 0.98 \\
\hline Total & 22 & 100 & 17 & 100 & 39 & 100 & 0.56 \\
\hline
\end{tabular}

Table.4 Comparison of seroprevalence of HBsAg with various studies in India

\begin{tabular}{|c|c|c|c|c|c|}
\hline Author & Place of study & Year of study & $\begin{array}{c}\text { No. of samples } \\
\text { tested }\end{array}$ & $\begin{array}{l}\text { No. of samples } \\
\text { positive }\end{array}$ & $\begin{array}{c}\text { Prevalence } \\
\%\end{array}$ \\
\hline Gokale et al., & Bagalkot & 2016-2017 & 3604 & 96 & 2.66 \\
\hline Quadri et al., & Bijapur & 2010 & 4283 & 70 & 1.63 \\
\hline Mindolli and Salmani & Bijapur & 2014 & 8300 & 146 & 1.76 \\
\hline Patil et al., & Solapur & 2010 & 767 & 23 & 2.99 \\
\hline Bulle et al., & Yavatmal & 2015 & 4649 & 73 & 1.57 \\
\hline Naqshbandi et al., & Srinagar & 2011-2013 & 1300 & 15 & 1.2 \\
\hline Bula et al., & Andhra Pradesh & $2015-2016$ & 24,028 & 733 & 3.05 \\
\hline Patil et al., & Karad & 2010-2011 & 7373 & 166 & 2.25 \\
\hline Bhaumik et al., & Tripura & 2011-2013 & 6202 & 222 & 3.6 \\
\hline Narayanswamy et al., & Chennai & - & 3182 & 105 & 3.3 \\
\hline Vazhagavandal et al., & Tiruchirapalli & $2010-2013$ & 19513 & 315 & 1.61 \\
\hline Kanodia et al., & Jaipur & $2012-2013$ & 74787 & 3092 & 4.13 \\
\hline Khatoon et al., & Lucknow & $2015-2016$ & 1537 & 61 & 3.9 \\
\hline Ghosh & Agartala & $2001-2005$ & 21121 & 1044 & 4.94 \\
\hline Dinesh et al., & Irula & - & 372 & 19 & 5.10 \\
\hline Sood & Jaipur & $2007-2008$ & 3196 & 28 & 0.87 \\
\hline Present study & Chamarajanagar & 206-2017 & 6905 & 39 & 0.56 \\
\hline
\end{tabular}

Fig.1 Seroprevalence of HBsAg among hospital based population

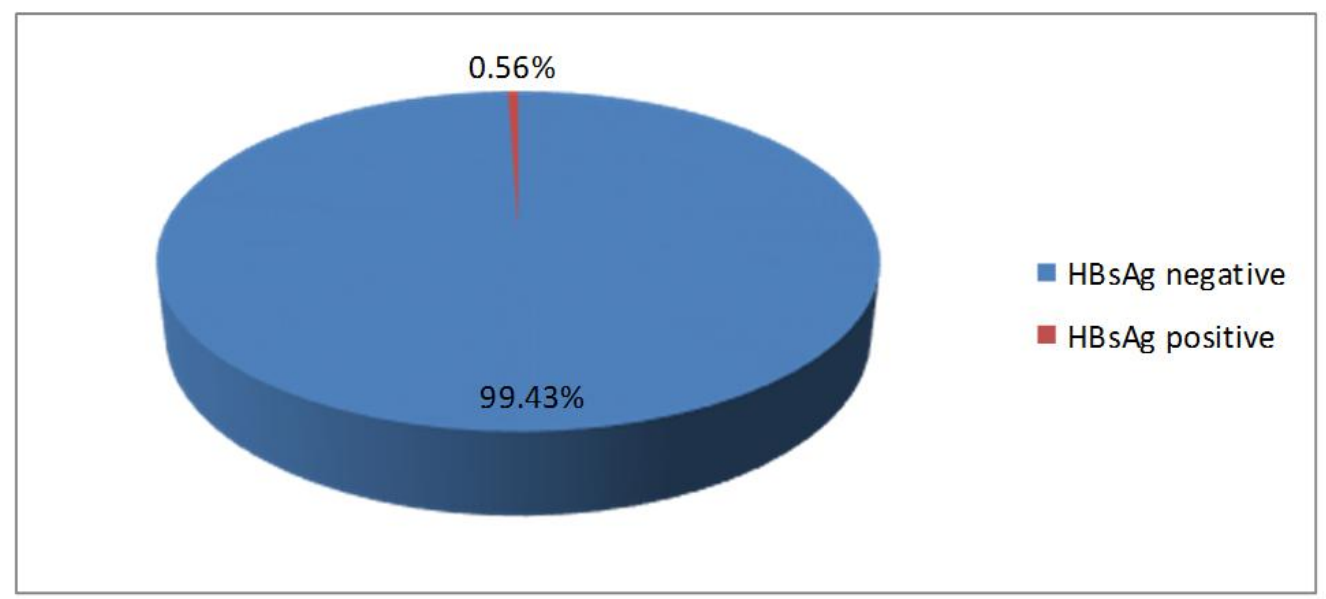


Hospital based studies conducted in Bijapur district of Karnataka in the year 2010 by Quadri et al., (2014) and by Mindolli and Salmani (2015) found seropositivity rates of $1.63 \%$ and $1.76 \%$ respectively and a rate of $2.66 \%$ in Bagalkot district (Gokale et al., 2017). Several other studies reported a seroprevalence rate of $<2 \%$ (Bulle, 2016; Naqshbandi, 2016; Vazhavandal, 2014). This difference in seropositivity could be due to differences in the study settings, differences in data collection methods, differences in the diagnostic tools used, differences in the profile of patients etc.

Seroprevalence rate in the present study was significantly higher in males $(0.98 \%)$ in concurrence with many other studies (Gokale et al., 2017; Quadri et al., 2010; Mindolli and Salmani, 2015; Patil, 2011; Bulle, 2016; Bula et al., 2017).

Higher infection rate in men could be due to their frequent exposure to risk factors such as injecting drug abuse, having multiple sexual partners or other risk behaviors. It is also hypothesized that females clear HBV more efficiently compared to males.

In our study, the seropositivity was directly proportional to age groups and there were no positive cases in below 20 years. Like our study, most of the studies observed seropositivity maximum after second decade of life because of their greater exposure and interaction in society as compared to children (Gokale et al., 2017; Mindolli and Salmani, 2015; Bulle, 2016; Bula et al., 2017). Further, absence of disease in younger age groups could be due to prevention of perinatal transmission of HBV by immunization in this locality. The findings in the present study likely reflect the patient population served by our hospital and indirectly estimates the disease burden in the community providing a good reference for future studies.
The present study highlights HBV infection rate in this part of state and its predominance in economically productive age groups thereby providing reference for future community based studies on epidemiology of HBV infection and also to formulate strategies to further reduce the seroprevalence rate.

\section{References}

Batham A, Gupta MA, Rastogi P, et al., 2009. Calculating Prevalence of Hepatitis B in India: Using Population Weights to look for Publication Bias in Conventional Metaanalysis. Ind J Paed. 76: 1247-1257.

Bhaumik P, Sil SK, Debnath K, Bhattacharjee S. 2014. Prevalence of Hepatitis B in Tripura: a community based study. Journal of evidence based Medicine and Healthcare. 1(17): 21562161.

Bula A, Gaddam SR. 2017. Seroprevalence of Hepatitis B surface antigen positive patients attending a tertiary care hospital in Srikakulam, Andhra Pradesh. Annals of Pathology and Laboratory Medicine. 4(1): 96-99.

Bulle PA, Tekam S, Gedam DS, Gujar V, Deshmukh D. 2016. Prevalence of Hepatitis B surface antigen (HBsAg) positivity among general population in Yavatmal (Maharashtra), India. Int.J.Curr.Microbiol. App.Sci. 5(7): 513-517.

Chaudhary A. 2004. Epidemiology of hepatitis B virus in India. Hep B Annual. 1:17-24.

Dinesh RE, Ramalakshmi S. 2017. Prevalence of Hepatitis B virus and associated risk factors in Irula tribal population. Asian J Pharm Clin Res. 10(8): 100-102.

Ghosh A. 2014. Prevalence of Hepatitis B Infection in a Tertiary Care Hospital, North East Region of India. Journal of Evolution of Medical and Dental Sciences. 3(41):1041310418.

Gokale SK, Sonth SB, Solabannavar SS. 2017. Seroprevalence of Hepatitis B virus among patients at a tertiary care centre in North Karnataka, India. Int.J.Curr.Microbiol.App. Sci. 6(9):755-757. 
Kanodia V, Yadav M, Bittu R, Maheshwari RK, Singh SK. 2015. Seroprevalence of Hepatitis B surface antigen in hospital based population of Jaipur, Rajasthan. International Medical Journal. 2(3):123-125.

Kaur H, Dhanao J, Oberoi A. 2000. Evaluation of rapid kits for detection of HIV, HBSAG and HCV infections. Indian J Med Sci. 54:432-4.

Khatoon R, Jahan N. 2016. Evaluation of seroprevalence of Hepatitis B virus infection among patients attending a hospital of semiurban North India using rapid immunoassay test. Niger Postgrad Med J. 23:209-214.

Mindolli PB, Salmani MP. 2015. Hepatitis B virus seroprevalence among hospital based general population in a tertiary care centre. Int.J.Curr.Microbiol.App.Sci 4(10): 964-967.

Naqshbandi I, Qadri SYA, Yasmeen N, Bashir N. 2016. Seroprevalence and risk factors of Hepatitis B virus infection among general population of Srinagar Kashmir. International Journal of Contemporary Medical Research. 3(4):1050-1054.

Narayanasamy K, Rajendran K, Radhakrishnan P, Annasamy C, Ramalingam S. 2014. Seroprevalence and factors associated with surface antigen of Hepatitis B virus and antiHepatitis $\mathrm{C}$ virus antibody among southern region of India, Tamil Nadu. Int $\mathbf{J}$ Infect Control. 11(1):1-10.

Patil SR, Ghorpade MV, Patil SS, Pawar SK, Mohite ST. 2016. Seroprevalence of Hepatitis-B surface antigen among the patients reporting at tertiary care Hospital from India. Bangladesh Journal of Medical Science. 15(3):455-459.

Patil SS, Nikam SA, Dama SB, Chondekar RP, Kirdak RV, Dama LB. 2011. Prevalence of hepatitis-B surface antigen (HBsAg) positivity in Solapur District, Maharashtra
State, India. Bangladesh Journal of Medical Science. 10(2): 91-94.

Prevention of Hepatitis B in India. An overview. World Health Organization, New Delhi 2002.

Quadri SA, Dadapeer HJ, Arifulla M, Khan N. 2013. Prevalence of Hepatitis B surface antigen in hospital based population in Bijapur, Karnataka. Al Ameen J Med Sci. 6(2):180-182.

Sato K, Ichiyama S, linuma $\mathrm{Y}$, Nada T, Shimokata K, Nakashima NJ. 1996. Evaluation of immunochromatographic assay systems for rapid detection of hepatitis B surface antigen and antibody, Dainascreen HBsAg and Dainascreen Ausab. Clin Microbiol. 34(6):1420-2.

Sood S, Malvankar S. 2010. Seroprevalence of Hepatitis B surface antigen, antibodies to the Hepatitis C virus, and Human Immunodeficiency virus in a hospital-based population in Jaipur, Rajasthan. Indian Journal of Community Medicine. 35(1):165169.

Sood S. 2013. Serological Evaluation of Hepatitis B Virus in outpatient Department patients of a private Hospital in North - West India. National $\mathrm{J}$ of Community Medicine. 4; 485488.

Torlesse H, Wurie IM, Hodges M. 1997. The use of immunochromatography test cards in the diagnosis of hepatitis B surface antigen among pregnant women in West Africa. $\mathrm{Br} \mathrm{J}$ Biomed Sci. 54(4):256-9.

Vazhavandal G, Bharadwaj VGB, Uma A, Rajalakshmi CP. 2014. Seroprevalence of hepatitis B virus among patients at a rural tertiary health care centre in South India: a four year study. Int J Res Med Sci. 2(1):310313.

\section{How to cite this article:}

Trupti B. Naik, J.V. Sathish and Mita D. Wadekar. 2018. Seroprevalence of Hepatitis B Surface Antigen (HBsAg) among Patients Attending a Tertiary Care Hospital at Chamarajanagar, Karnataka, India. Int.J.Curr.Microbiol.App.Sci. 7(01): 1279-1284. doi: https://doi.org/10.20546/ijcmas.2018.701.156 